\title{
Development Potential of Integrated Farming System (Local Cattle - Food Crops)
}

\author{
Femi Hadidjah Elly ${ }^{1}, *$, Agustinus Lomboan ${ }^{1}$, Charles L. Kaunang ${ }^{1}$, Meiske Rundengan ${ }^{1}$, \\ Zulkifli Poli $^{1}$ and Syarifuddin ${ }^{2}$ \\ ${ }^{1}$ Faculty of Animal Husbandry, University of Sam Ratulangi, Manado, North Celebes, Indonesia \\ ${ }^{2}$ PEMDA, North Bolaang Mongondow, Indonesia \\ *Corresponding author email: femi_elly@yahoo.co.id
}

\begin{abstract}
Local cattle farming as an income source for farmers in rural areas is mostly developed traditionally. The local cattle farm continues, even though it is a side business, but is a mainstay in supporting national beef needs. The problem is whether integration of local cattle and food crops have the potential to be developed by farmers. The research was conducted to determine the potential integration of local cattle local and corn in North Bolaang Mongondow Regency. A survey method using a purposive sampling selected 60 farmers from Sangkub District where farmers practiced an integrated cattle-crops farming. Data were subjected to proximate and feasibility analysis. The results showed that the total cattle owned by respondents were 209 . The feed consisted of grass and corn waste, with an average consumption of 5.33 and $11.15 \mathrm{~kg} / \mathrm{head} /$ day, respectively. A proximate analysis of waste corn reported $86.48 \%$ dry material, $7.36 \%$ crude protein, $1.84 \%$ fat, $28.95 \%$ crude fiber, $9.10 \%$ ash and $68.18 \%$ carbohydrate. Respondents' income from cattle farming in Bintauna and Sangkub Districts were Rp. 151,000,000 vs. Rp. 169,900,000, production costs were Rp. 101,150,625 vs. Rp. $107,298,593.8$, and RC ratio was 1.49 vs. 1.58. In conclusion, corn waste consumption was greater (67.66\%) than the grass. RC ratio value $>1$ indicated that cattle farming was feasible. The corn-cattle farming integration system can minimize environmental pollution because it enables the concept of LEISA (Low External Input Sustainability Agriculture).
\end{abstract}

Key words: integration, local cattle, food crops, low external input sustainability agriculture

Abstrak. Peternakan sapi lokal sebagai sumber pendapatan petani peternak di pedesaan, sebagian besar dikembangkan secara tradisional. Usaha peternakan sapi lokal tersebut tetap bertahan walaupun sebagai usaha sambilan dan menjadi andalan dalam menunjang kebutuhan daging sapi secara nasional. Permasalahannya apakah peternakan sapi lokal terintegrasi dengan tanaman pangan memiliki potensi untuk dikembangkan oleh petani peternak. Penelitian ini bertujuan untuk mengetahui potensi integrasi ternak sapi local-jagung di Kabupaten Bolaang Mongondow Utara. Metode penelitian yang digunakan adalah metode survei. Lokasi penelitian adalah Kecamatan Bintauna dan Sangkub yang ditentukan secara purposive sampling yaitu kecamatan yang memiliki petani peternak dengan sistem usahatani ternak sapi-jagung. Jumlah responden 60 petani. Analisis data yang digunakan adalah analisis proksimat dan analisis kelayakan. Hasil penelitian menunjukkan bahwa total pemilikan ternak sapi milik responden sebanyak 209 ekor. Pakan yang dikonsumsi adalah rumput dan limbah jagung. Rata-rata konsumsi rumput sebanyak 5,33 kg/ekor/hari dan konsumsi limbah jagung sebanyak $11,15 \mathrm{~kg} / \mathrm{ekor} /$ hari. Analisis proksimat limbah jagung menunjukkan bahan kering $86,48 \%$, protein kasar 7,36\%, lemak 1,84\%, serat kasar $28,95 \%$, kadar abu $9,10 \%$ dan karbohidrat $68,18 \%$. Pendapatan penjualan sapi oleh responden di Kecamatan Bintauna Rp 151.000.000, biaya produksi Rp 101.150.625, dan RC ratio 1,49. Pendapatan responden di Kecamatan Sangkub Rp 169.900.000, dengan biaya produksi Rp 107.298.593,8, dan RC ratio 1.58. Berdasarkan hasil penelitian dapat disimpulkan bahwa konsumsi limbah jagung lebih besar $(67,66 \%)$ dibanding konsumsi rumput. Usaha ternak sapi lokal layak dijalankan dilihat dari nilai R/C ratio lebih besar satu. Sistem integrasi ternak sapi lokal-jagung dapat meminimalkan pencemaran lingkungan karena konsep LEISA (Low External Input Sustainability Agriculture) dapat diaplikasikan.

Kata kunci: integrasi, sapi lokal, tanaman pangan, ramah lingkungan

\section{Introduction}

Local cattle farming as a source of income for farmers in rural areas is mostly developed traditionally. The local cattle farming persists even though it is a side business and becomes a mainstay in supporting national beef demand. Beef demand tends to increase due to the growing population, income and even public education in general. 
Local cattle is a commodity that plays a role in rural agribusiness. These cattle also act as biological and economical chains in farming systems and are integrated with other farms. Local cattle farmers utilize food crops as sustainable feed to reduce feed cost. On the other hand, cattle waste can be used as organic fertilizer to improve soil fertility (Hanafi, 2016). Local cattle can produce $10 \mathrm{~kg}$ of solid waste per day which is processed to $3 \mathrm{~kg}$ of organic fertilizer. According to Muis (2015), one adult cattle can produce $12-15 \mathrm{~kg} /$ day of solid waste and 3-5 liters/day urine. It shows that local cattle farms are mutually symbiotic with food crops. According to Lakitan and Gofar (2013), compost is an option to support the increase of rice plant productivity.

The term 'farming integration' is better known as Integrated Farming System, which is very productive and profitable (Channabasavanna et al., 2009). Since 1977, the integration system has been claimed to reduce land degradation and productivity compared to conventional crop systems. Furthermore, the management of the integrated farming system can increase farmers' income.

The problem is whether local cattle farms integrated with food crops are potentially developed by farmers. Integrating local cattle and food crops by rural farmers can occur naturally and is traditional. This research was conducted to determine the potential extent of developing the integration of local cattle and food crops in the rural.

\section{Materials and Methods}

This research was conducted in the North Bolaang Mongondow Regency. The research materials were local cattle, feed, and corn waste. Local cattle were stated from the total cattle owned by farmers as samples. Cattle feed is forage consumed, i.e. grass and corn waste. Corn waste is fresh corn straw consumed by local cattle. A survey was conducted with a purposive sampling to determine the research locations, i.e. Bintauna and Sangkub Districts where local farmers were developing an integrated local cattle-corn plant farming. A simple random sampling selected 60 farmers. Data were subjected to a descriptive, proximate analysis and feasibility analysis.

\section{Results and Discussion}

Local cattle in the research area were used as savings to be sold at any time for the farmers household. Local cattle as a business provided an added value in the farming system, which was managed by farmers. The results showed that local cattle were traditionally developed which allowed cattle to graze on agricultural land and moved from one field to another. Grass that grows on agricultural land is used as local cattle feed. On the other hand, some farmers who developed corn plants as a source of income, also use fresh corn waste as feed. Total respondents, total cattle owned and feed consumption (grass and corn waste), according to research results are presented Table 1.

Table 1 shows that feed consumed by local cattle was not as recommended (30 $\mathrm{kg} / \mathrm{head} /$ day). According to Elly et al. (2018), this condition causes low cattle productivity. This research was supported by Nurdiati et al. (2012), Susanti et al. (2013), Sitindaon (2013), and Saragi (2014), that cattle productivity in several regions in Indonesia depends on feed.

The utilization of fresh corn waste as feed can be improved, considering that North Bolaang Mongondow Regency is one of the corn development centre as a source of income. Sangkub District develops corn plants by utilizing land up to 300 ha. Proximate analysis results (Institute for Industrial Research and Standardization, 2018) reported that corn waste contained $86.48 \%$ dry matter, $7.36 \%$ crude protein, $1.84 \%$ fat, $28.95 \%$ crude fiber, $9.10 \%$ ash content and $68.18 \%$ carbohydrates.

It indicated that the concept of integration of local cattle and corn plants traditionally has been applied to farmers who are members of 
Table 1. Number of respondents, number of local cattles, consumption for grass and fresh corn waste

\begin{tabular}{lcc}
\hline \multirow{2}{*}{ Description } & \multicolumn{2}{c}{ District } \\
\cline { 2 - 3 } & Bintauna & Sangkub \\
\hline Number of respondents (farmers) & 30 & 30 \\
Number of local cattle (head) & 128 & 81 \\
Consumption of feed (kg/cattle/day) & & \\
Grass & 5.17 & 5.50 \\
Fresh corn waste & 10.93 & 11.37 \\
\hline
\end{tabular}

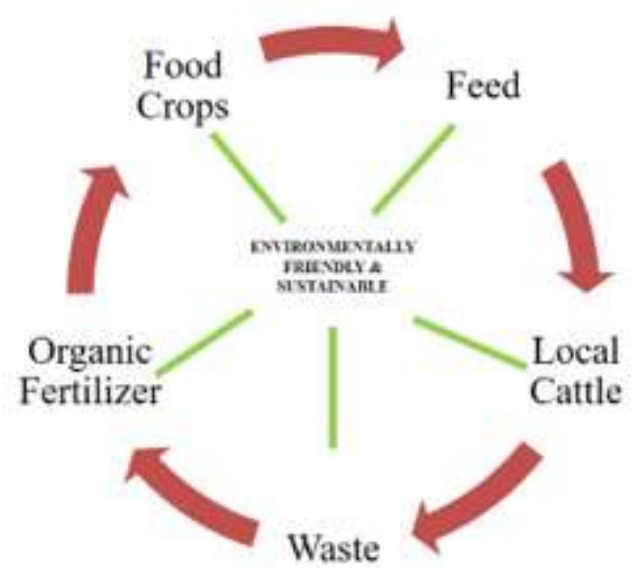

Figure 1. The concept of local cattle-food crops integration

the group. Although some farmers allow the corn waste to dry up, some prefer to burn it which contributes to environmental pollution. The government programs to support farmers' income include increasing local cattle population. However, it potentially increases cow waste.

The results of the study showed that local cattle waste was grounded and process into solid and liquid organic fertilizer. This activity was conducted by some farmers who were also the members of a formal institutions in the community (Suprianto, 2016) which allows farmers' collaborate to improve bargaining power and share knowledge.

The results showed the respondents' income from selling cattle in Bintauna District was Rp. 151,000,000. The total production cost which included labor costs and feed costs (grass and corn waste) was Rp 101,150,625; therefore, the profit gained was $\mathrm{Rp} 49,849,375$ and the $\mathrm{RC}$ ratio was 1.49 . The respondent's income in Sangkub District was Rp. $169,900,000$, and the total production cost was Rp.107,298,593.80; therefore, the profit was Rp. $62,601,406.25$ and RC ratio was 1.58 . The indication of developing an integrated local cattle and corn farming was supported by Elly (2008) and Elly et al. (2008). The concept of cattle-plants integration has been proposed by several researchers (Walia and Kaur, 2013, Forero and Gonzalo, 2013, Swarnam et al., 2014, Munandar et al., 2015, Ezeaku et al., 2015, and Wahyuni, 2015). The result indicated that the concept of integration of local cattle and food crops is simply formulated in Figure 1.

Figure 1 shows an uninterrupted flow of resources where food crop waste can be used as an input for beef cattle. Organic fertilizers are used to increase soil fertility, and all activities lead to environment-friendly and sustainable activities. The concept shows a zero waste concept which means there is no waste that is not utilized.

The integration system of local cattle and corn with the zero waste approach according to Wulandari (2014) is an improvement of the intensification system that has developed in the community. The zero waste farming model is an agricultural model that prevents wasting residuals (Sunanto and Nasrullah, 2012). Therefore, farmers who apply the LEISA (Low External Input Sustainability Agriculture) concept can minimize production costs (Erlina and Anggreini, 2014). 


\section{Conclusions}

Corn waste consumption was greater $(67.66 \%)$ that grass consumption. RC ratio value $>1$ indicated that cattle farming was feasible. The corn-cattle integrated farming system can minimize environmental pollution because it applies the concept of LEISA (Low External Input Sustainability Agriculture).

\section{Acknowledgement}

The authors express their gratitude to DRPM DIKTI for the research funding through Research of Higher Educational Applications scheme.

\section{References}

Channabasavanna, A. S., D. P. Birodar, K. N. Prabhudev and M. Hegde. 2009. Development of profitable integrated farming system for small and medium farmers of tungabhadra project area of karnataka. India. Karnataka J. Agric. Sci. 22 (1): 25-27.

Elly, F. H., A. H. Salendu, ChL Kaunang, Indriana, Syarifuddin and R. Pomolango. 2018. Empowerment of Farmers in Efforts to Develop Sustainable Cattle Farming in Sangkub District Regency of North Bolaang Mongondow, North Sulawesi Province, Indonesia. Proceeding The Fourth International Seminar on Animal Industry. IPB International Convention Centre, Bogor Indonesia, August, 28-30 2018.

Elly, F. H. 2008. Impact of Transaction Costs on Household Economic Behavior of Farmers in Cattle-Crop Farming in North Sulawesi. Doctoral Dissertation. Postgraduate Program in Bogor Agricultural Institute, Bogor.

Elly, F. H., B. M. Sinaga, S. U. Kuntjoro and N. Kusnadi. 2008. Development of Cattle Farming through Integration of Cattle-Plants in North Sulawesi. Journal of Agricultural Research and Development. Agricultural Research and Development Center, Ministry of Agriculture, Bogor.

Erlina, Y. and T. Anggreini. 2014. Study of management of integration of corn plants and cattle in Kalampange Village, Sabangan SubDistrict. J. SEA (Journal of Socio Agricultural Economics). 10 (1) : 01-08.

Ezeaku, I. E., B. N. Mbah, K. P. Baiyeri and E. C. Okechukwu. 2015. Integrated crop-livestock farming system for sustainable agricultural production in Nigeria. African Journal of Agricultural Research. 4268-4274.

Forero, B. and A. Gonzalo. 2013. Integrated farming system to the foothill-regions of ColombaAriporo System (A.S). Journal Technology. 12 (2) : 24-34.

Hanafi, H. 2016. The Role of the cage of the communal system of beef cattle, integrated agricultural waste in supporting food sovereignty in Yogyakarta. Agros. 18 (2) : 126133.

Institute for Industrial Research and Standardization. 2018. Proximate Analysis of Corn Waste. Institute for Industrial Research and Standardization, Manado City.

Lakitan, B. and N. Gofar. 2013. Technology Innovation Policy for Sustainable Suboptimal Land Management. Proceedings of the Suboptimal National Seminar "Intensification of Suboptimal Land Management in Order to Support National Food Independence". Palembang 20-21 September 2013. 5-14.

Muis, J. M. 2015. Performance and prospect of development of environmentally friendly beef cattle in West Sumatera. Widyariset. 18 (1) : 5970.

Munandar, F. G. Yakup, R. Hayati and Al Munawar. 2015. Crop-cattle integrated farming system : an Alternative of climatic change mitigation. Media Peternakan. 38 (2) : 95-103.

Nurdiati, K., E. Handayanta and Lutojo. 2012. Efficiency of beef cattle production in the dry season in the regional people's ranch dryland agriculture in Gunung Kidul Regency. Tropical Animal Husbandry. 1 (1) : 52-58.

Saragi, M. P. 2014. Potential and quality of agricultural waste as feed in Bandung and Bogor Regency for development of cultivation of dairy cattle. Thesis. Postgraduate School, IPB Bogor.

Sitindaon, S. H. 2013. Potential inventory of ruminant animal feed materials in Riau Province. Journal of Breeders. 10 (1) : 18-23.

Sunanto and Nasrullah. 2012. Study of Zero Waste Agriculture Model with Approach to Integration of Corn Crops-Cattle in South Sulawesi. Proceedings of Insinas. 223-228.

Suprianto. 2016. Study of application of artificial insemination technology in efforts to increase productivity and revenue of cattle farming in Tasikmalaya Regency. Agribusiness Pulpit. 1 (3): 211-225.

Susanti, A. E., A. Prabowo and J. Karman. 2013. Identification and Solving the Problems of Provision of Cattle Feed in Supporting People's Livestock Businesses in South Sumatra. Proceedings. National Seminar on Sustainable 
Livestock. Livestock Agribusiness Innovation for Food Security. Faculty of Animal Husbandry, Padjadjaran University, Bandung. 127-132.

Swarnam, T. P., A. Velmurugan, Z. George, N. Ravisankar, T. P. Sai, S. D. Ray and P. Srivastava. 2014. Integrated farming system for sustainable livelihood in Tribal Areas of Nicobar Island, India. Journal of the Andaman Science Association. 19 (1) : 19-22.

Wahyuni, R. 2015. Mastery structure of land resources and contribution of beef cattle farming to farmer household income. Widyariset. 18 (1) : 79-90.

Wulandari, W. A. 2014. Integration of Cows with Corn in Sub Optimal Land in Bengkulu Province. Report. Institute for Agricultural Technology Studies, Bengkulu.

Walia, S. S. and N. Kaur. 2013. Integrated farming system-an ecofriendly approach for sustainable agricultural environment. A Review. Greener Journal of Agronomy Forestry and Horticulture. 1 (1) : 001-011. 